\title{
尿路変向術100例の検討
}

$\begin{array}{ccccc} & \text { 田 } & \text { 中 } & \text { 成 } & \text { 美 } \\ & \text { 原 } & & \text { 暢 } & \text { 助 } \\ & \text { 森 } & \text { 田 } & \text { 辰 } & \text { 男 } \\ & \text { 石 } & \text { 川 } & \text { 真 } & \text { 也 } \\ \text { 自治医科大学泌原器科学教室 } & \text { 森 } & \text { 口 } & \text { 英 } & \text { 男 } \\ (\text { (主任: 米瀬脊行教授) } & \text { 小 } & \text { 林 } & & \text { 裕 } \\ & \text { 戸 } & \text { 塚 } & \text { 一 } & \text { 彦 } \\ & \text { 大 } & \text { 場 } & \text { 修 } & \text { 司 } \\ & \text { 德 } & \text { 江 } & \text { 章 } & \text { 彦 } \\ & \text { 米 } & \text { 瀬 } & \text { 泰 } & \text { 行 }\end{array}$

\section{URINARY DIVERSION; REVIEW OF 100 CASES}

Shigemi Tanaka, Yohsuke Hara, Tatsuo Morita, Shinya Ishikawa,

Hideo Moriguchi, Yutaka Kobayshi, Kazuhiko Tozuka, Shyuji Ohba, Akihiko Tokue and Yasuyuki Yonese

Department of Urology, Jichi Medical School

(Director: Prof. Y. Yonese)

The late results on 100 patients who underwent urinary diversion at the Department of Urology, Jichi Medical School during the period of 1974 through 1983 were reviewed. The ages ranged from 4 to 84 years old, with sex ratio $(\mathrm{M} / \mathrm{F}) 3.5$ to 1 . Bladder tumor was the indication of the operation in 76 cases, uterine cancer in 6 , urethral cancer in 4 , prostatic cancer in 3 , the other malignancies in 3 and benign disease in 8.

Cystostomy was performed in 8 cases, nephrostomy in 7, intubated ureterocutaneostomy in 56 , ileal conduit in 9 and uretrosigmoidostomy in 20 as the method of urinary diversion.

The relative 5 -year survival rate was $51.2 \%$ as a whole. That of patients who underwent total cystectomy for bladder transitional cell cancer was $58.2 \%$.

In the cases who underwent total cystectomy and urinary diversion, the postoperative mortality rate was $4.9 \%$ ( 3 cases) and details of postoperative complications were reviewed.

要旨：自治医科大学泌尿器科において，1974年 4 月 15 日の開院より 9 年間に尿路変向術が施行された症 例は 100 例で, 男子78例, 女子 22 例, 男女比は 3.5 対 1 であった。最年少者は 4 歳, 最年長は84歳, 平均 年齢は60.2歳であった。原因疾患は膀胱腫瘍 76 例, 子宮癌 6 例, 尿道癌 4 例, 前立腺癌 3 例その他の悪 性腫瘍 3 例で良性疾患は 8 例であった。

施行された尿路变向術は, 膀胱瘻造設術 8 例, 腎瘦造設術 7 例, カテーテル尿管皮層瘦造設術 56 例, 回腸導管造設術 9 例，尿管 S 状結腸吻合例であった。

100 例全例の 5 年相対生存率は $51.2 \%$ で, 膀胱移行上皮癌のため膀脱全摘術を施行した 53 例の 5 年相対 生存率は $58.7 \%$ であった。

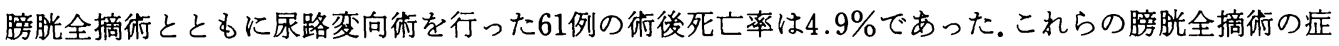
例の術後早期合併症及び晚期合併症について尿路変向術式別に比較, 検討した. 


\section{緒言}

尿路の変向術は従来より多くの術式が工夫されてき たが，いずれの方法もそれぞれ長所, 短所があり, ま た術式により手術をらける患者の予後, 社会復㷌後の 生活に与える影響はさまざまである。尿路变向術とし てぞの術式を選ぶかは，個々の症例において原疾患， 全身状態, 合併症, 年齢, 性, 生活環境などの多くの 要因を考慮して決定することになる。

今回，著者らは1974年 4 月 15 日の自治医科大学附属 病院の開院より，1983年 4 月 14 日までの 9 年間に当院 泌尿器科に损いて経験した尿路変向術症例 100 例につ いて検討し，特に膀胼全摘術ともに施行された尿路変 向術の術式別の術後早期合併症及び晚期合併症をまと めたので報告する。

\section{対象及び方法}

1974年 4 月 15 日より 1983年 4 月 14 日までの 9 年間に 当科で尿路変向術を施行された 100 例を対象とした. こ のうち膀羘全摘術之同時に尿路変向術をらけた 61 例で は術後早期及び晚期合併症を調べた。手術死亡例を除 く観察期間は最短 1 カ月, 最長 8 年であった. 膀胼全 摘術にともなって施行された尿路変向術は, 原則とし て膀胼摘出後に行い, 一期的に施行したものである. 回腸導管造設術及び尿管 S 状結腸（直腸）吻合術では, 尿管と腸管は mucosa to mucosa，あるいは Sampson 法による吻合を行った。尿管皮膚瘻造設術は, 全例力 テーテル尿管皮膚瘦としたものである.

生存率の算出は, 1963年の International Symposium on End Results of Cancer Therapy で統 一された方法 ${ }^{122}$ に基づいて実測生存率を求め，この実 測生存率を昭和 50 年及び昭和 55 年生命表より算出した 期待生存率で除して相対生存率を求めた.

\section{結果}

患者の手術時の年齢は, 最年少 4 歳から最年長 84 歳 で平均年龄は 60.2 歳であった。男子が78例，女子 22 例 で男女比は3.5：1であった（Table 1).

施行した尿路変向術の原因疾患と術式別の症例数を Table 2に示した。尿管 S 状結腸 (直腸) 吻合術後に尿
管吻合部よりの尿漏出などのため再吻合術を行ったも の 4 例，尿管皮膚瘦造設術を行ったもの 4 例，また尿 管皮膚瘻造設術後に尿管狭窄をきたしカテーテル交換 ができず腎瘻造設を行ったもの 8 例，尿管皮膚瘦の再 建術を行ったものが 6 例あり, 総手術数は 122 回となっ ている．原因疾患としては膀胱腫瘍が76例と最も多 かったが，このうち 2 例は腎孟，尿管腫瘍に続発した ものである，その他，子宮癌 6 例，尿道癌 4 例など悪 性腫瘍が92例を占め, 良性疾患は 8 例であった. 膀胱 腫瘍の組織学的分類を Table 3 K示した。 不明の 2 例 は他施設にて膀胼全摘術をらけたためである，尿路変 向術を施行された 100 例全例の相対生存率は, 1 年生存 率 $61.4 \%$ (標準誤差 $5.0 \%$ )，2 年生存率 $49.2 \%$ (標準 誤差 $5.3 \%$ )， 3 年生存率 $51.1 \%$ （標準誤差 $5.5 \%$ ） 4 年 生存率 $49.0 \%$ (標準誤差 $5.6 \%$ ), 5 年生存率 $51.2 \%$ (標 準誤差5.9\%) であった（Fig. 1).

膀脱移行上皮癌のため膀胼全摘術とともに尿路变向 術を施行された症例は55例あり, 腎孟腫瘍, 尿管腫瘍 の治療後に発生した膀脂腫瘍の 2 例を除いた53例（男 子 48 例, 女子 5 例, 28 歳から 78 歳, 平均 61.8 歳) の相 対生存率は 1 年生存率 $77.7 \%$ (標準誤差 $6.0 \%$ ), 2 年 生存率 $57.3 \%$ (標準誤差 $7.2 \%$ ), 3 年生存率 $60.0 \%$ (標 準誤差7.5\%)， 4 年生存率 $56.3 \%$ (標準誤差 $7.8 \%$ ), 5 年生存率 $58.2 \%$ (標準誤差 $8.0 \%$ )であった (Fig. 2).

膀胱腫瘍の進展により閉塞性尿路障害を生じたた め, あるいは膀胱全摘術の適応とならず尿路変向術の みを施行された症例は15例で男子14例，女子 1 例， 46 歳から84歳, 平均年龄65.7歳であった。このらち膀脱 移行上皮癌の症例は 14 例で, 追跡不能の 3 例（術後73 日，360日，398日まで経過観察）を除いた尿路変向術 後の平均生存期間は約 167 日であった. 1 例は膀胀腺癌 の症例で術後10日で癌死した。

膀胱腫瘍のため膀胱全摘術とともに施行された尿管 $\mathrm{S}$ 状結腸（直腸）吻合術 20 例, 回腸導管造設 9 例, 尿 管皮膚造設術 32 例の術後早期合併症及び晚期合併症を それぞれ Table 4，5，6に示した。

尿管 S 状結腸（直腸）吻合術を施行された20例は,

Table 1. Age distribution

\begin{tabular}{l|c|c|c|c|c|c|c|c|c}
\hline & $0 \sim 9$ & $10 \sim 19$ & $20 \sim 29$ & $30 \sim 39$ & $40 \sim 49$ & $50 \sim 59$ & $60 \sim 69$ & $70 \sim 70$ & $80 \sim$ \\
\hline male & 0 & 2 & 1 & 0 & 11 & 16 & 26 & 19 & 3 \\
female & 1 & 0 & 0 & 1 & 3 & 7 & 4 & 6 & 0 \\
\hline total & 1 & 2 & 1 & 1 & 14 & 23 & 30 & 25 & 3 \\
\hline
\end{tabular}


Table 2. Cause and winary diversion

\begin{tabular}{l|r|r|r|r|r|r}
\hline & $\begin{array}{c}\text { cysto- } \\
\text { stomy }\end{array}$ & UC & NS & US & ID & total \\
\hline bladder tumor & 1 & 44 & 2 & 20 & 9 & 76 \\
\hline uterine cancer & & 6 & & & & 6 \\
\hline urethral cancer & 3 & 1 & & & & 4 \\
\hline prostatic cancer & 2 & 1 & & & & 3 \\
\hline penile cancer & 1 & & & & & 1 \\
\hline ureteral tumor & & 1 & & & & 1 \\
\hline retroperitoneal tumor & & 1 & & & & 1 \\
\hline renal stone & & & 2 & & & 2 \\
\hline hydronephrosis & & 1 & 1 & & & 2 \\
\hline pyonephrosis & & 1 & & & & 1 \\
\hline renal tubelculosis & & & 1 & & & 1 \\
\hline VUR & & & 1 & & & 1 \\
\hline urethral stenosis & 1 & & & & & 1 \\
\hline & 8 & 56 & 7 & 20 & 9 & 100 \\
\hline
\end{tabular}

UC : wceterocutaneostomy

US : wceterosigmoidostomy

ID : ileal condait

NS : nephrostomy

Table 3 Histopathological distribution of blaclder tumor

\begin{tabular}{|c|c|c|}
\hline Transitional cell ca. & 69 & $90.8 \%$ \\
\hline Adenoca. & 2 & $2.6 \%$ \\
\hline Squamous cell ca. & 1 & $1.3 \%$ \\
\hline Transitional cell ca. + adenoca. & 1 & $1.3 \%$ \\
\hline malignant lymphoma & 1 & $1.3 \%$ \\
\hline not listed & 2 & $2.6 \%$ \\
\hline total & 100 & $100 \%$ \\
\hline
\end{tabular}

男子 17 例，女子 3 例， 31 歳から 73 歳，平均年龄 51.7 歳 であった，尿管はできるかぎり肛門側に吻合し，20例 中 12 例は $\mathrm{S}$ 状結腸に，8 例は直腸に吻合した，尿管吻 合部より尿漏出をきたした 7 例のらち 3 例は再吻合術 を要し， 2 例は尿管皮膚瘦造設術を行った。 2 例は保 存的治療で治癒した。腸瘻の 3 例のらち 2 例は手術を 要し，1例は自然治癒した。晚期合併症では, 高クロー ル血症が 9 例にみられた。重曹の投与量は症例により 異なるが $0 \sim 12 \mathrm{~g} /$ 日である。 また腎機能低下のため 1 例が再吻合術， 1 例が尿管皮凊㾞造設術，癌浸潤のた め 1 例が尿管皮虚瘦造設術を必要とした。
Fig. 1 5-year survival rate urinary diversion : 100 cases

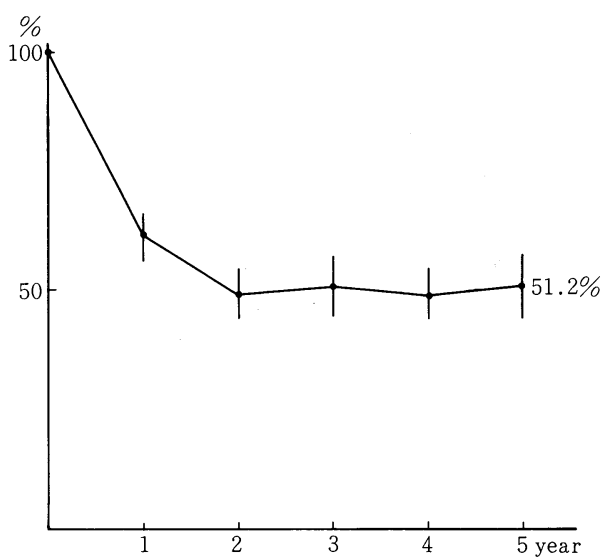

Fig. 2 5-year survival rate total cystectomy : 53 cases

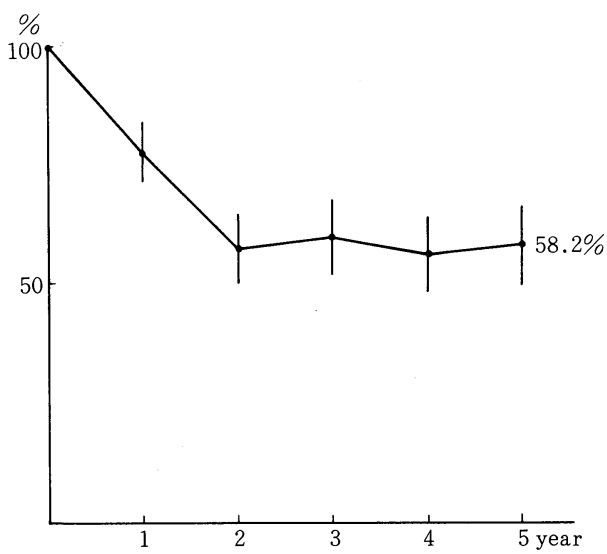

Table 4 Complications after ureterosigmoidostomy

Early complications

\begin{tabular}{|c|c|c|c|}
\hline urinary leakage & 7 & hyperchloremic acidosis & 9 \\
\hline fecal fistula & 3 & mild hydronephrosis & 7 \\
\hline wound infection & 3 & renal dysfunction & 6 \\
\hline liver dysfunction & 3 & non-visualized kidney & 4 \\
\hline atelectasis & 1 & pyelonephritis & 4 \\
\hline intrapelvic abscess & 1 & moderate hydronephrosis & 2 \\
\hline epididymitis & 1 & renal stone & 1 \\
\hline
\end{tabular}

回腸導管造設術を施行された 9 例は, 男子 7 例，女 子 2 例， 47 歳から73歳，平均年齢59.8歳であった。 1 例が術後急性腎不全をおこし, 創哆開, 肺炎, 敗血症 
Table 5 Complications after ileal conduit

Early complications

\begin{tabular}{|c|c|c|c|}
\hline dehiscence & 2 & non-visualized kidney & 1 \\
\hline acute renal failure & 1 & mild hydronephrosis & 1 \\
\hline ileus & 1 & & \\
\hline
\end{tabular}

Table 6 Complications after ureterocutaneostomy

\begin{tabular}{l|c}
\multicolumn{2}{c}{ Early complications } \\
\hline wound infection & 5 \\
\hline liver dysfunction & 4 \\
\hline ileus & 3 \\
\hline dehiscence & 2 \\
\hline duodenal ulcer & 1 \\
\hline fecal fistula & 1 \\
\hline
\end{tabular}

Late complications

\begin{tabular}{l|c}
\hline pyelonephritis & 14 \\
\hline ureteral stricture & 11 \\
\hline renal dysfunction & 8 \\
\hline moderate hydronephrosis & 3 \\
\hline parastomal pain & 2 \\
\hline renal stone & 1 \\
\hline
\end{tabular}

を合併して術後 2 力月で死亡した，症例数が少ないこ ともあり，腎昷腎炎，電解質異常の症例は経験してい ない，導管周囲の皮膚炎については軽度のものは記載 されていないことも多く対象からはずした。

膀羘全摘術とともに尿管皮膚造設術を施行された症 例は32例で, 男子29例, 女子 3 例, 47歳から78歳で平 均年齢61.5歳であった。術後早期合併症として Table 6にあげたものは,むしろ膀胼全摘術の合併症というべ きものであるが，穿孔性腹膜炎の 1 例，吐血の 1 例は 術後死亡例である。晚期合併症では，腎跙腎炎が14例 (43.8\%)と高率にみられた。このうち 1 例はカテーテ ル交換後に敗血症をおこし死亡した。また腎機能障害 は，BUN, Cr 值の上昇をきたしたものであるが， 8 例 中 4 例は腎孟腎炎をくりかえした症例である。尿管狭 窄はカテーテル交換がスムースにいかず，遠視，ガイ ドワイヤー使用などの処置を要した 11 例中 7 例で尿管 皮膚瘻造設術あるいは腎瘻造設術が行われた。この点 に関しては，尿管皮膚造設術を施行された全症例56例 についてみると尿管狭窄のため 8 例が腎瘻造設術, 6 例が尿管皮膚瘻の再建術を行っており，14例（25\%） の患者が再手術をらけたことになる。

\section{考按}

著者らが施行した尿路変向術の症例 100 例の 5 年生 存率は $51.2 \%$ あ゙あた。これは原疾患による影響が大 きく尿路変向術の予後とはいえないが, 100例のらち92 例までが膀脱腫瘍をはじめとする悪性腫瘍であること を考えれば比較的良好な成績と言えよ5。また膀胼移 行上皮癌に対して膀胼全摘術を施行した53例の 5 年相
対生存率は $58.2 \%$ で, Cox ら ${ }^{3)}$ の $32.4 \%$, 高安ら $49 \%$ ，佐川ら 5 の $60 \%$ ，上門ら ${ }^{6}$ の $51.2 \%$ と比較してほ ぼ一致する成績であった。

悪性腫瘍の末期の症例で，腫瘍の浸潤のため閉塞性 尿路障害をきたすことはよく経験することであるが, このような症例の尿路変向術後の平均生存期間は約 167日であった（膀脱移行上皮癌11例）。原疾患に対す る治療は，全身状態が悪化していることが多く副作用 の少い非特異的免疫療法しか行えなかった症例が皃と んどであった。

上部尿路変向術式としては，回腸導管造設術が代表 的な方法として多くの施設で行われている(5)7)8). 近年, 回腸導管造設術の長期観察症例が増えるにつれて，腎 孟腎炎, 結石形成, 水腎症, 明らかな通過障害を併わ ない進行性の腎障害などの晚期合併症が予想以上の頻 度でみられることが明らかになった ${ }^{9)}$.これらの晚期 合併症は導管尿管逆流によるものであるとされ, 結腸 導管, 回盲部導管, あるいは逆流防止術を施行した回 腸導管造設術などの工夫がなされてきている10) 12). 著 者らの施設で行った回腸導管造設例は 9 例と少く，そ の観察期間も 3 年以内と短いため本稿では他施設の成 績13) 15) との比較はできない.

尿管 S 状結腸吻合術は, 1852年 Simonによって最初 に行われた といわれるが, hyperchloremic $\operatorname{acidosis}^{17)}$, 上行性感染, 吻合部狭窄, 縫合不全などの 合併症が多く予後が悪いことから一時期あまり行われ なくなった。しかし吻合術式の改良, 化学療法剂の進 歩, hyperchloremic acidosis の発生機序及び予防法の 知識の普及, さらに外尿瘻がなく器具の装着が不用で ある利点があり，本術式が再び採用される傾向にあ る ${ }^{18) 19)}$. しかし本術式施行後に尿管吻合部付近に腫瘍, 特に癌の発生が抗こることも報告されている ${ }^{20121)}$. 手 術から腫瘍発生までの期間は 1 年から 49 年で平均 22 年 とされているが22)23), Leadbetter は40歳以後に手術を らけた患者では, 術後 $5 \sim 14$ 年, 平均 8.7 年と比較的短 期間に癌の発生がみられ，また一般には高齢者に結腸 癌, 直腸癌の発生が多いのとは逆に, 尿管 S 状結腸吻 合術をらけた患者では，40歳以上の者に比べ40歳以下 の者に癌の発生が多いと報告している ${ }^{21)}$ ：このような 吻合部の腫瘍の発生に対して, IVP, 注腸造影, 大腸鏡 などによる定期的なfollow upが必要であろ $5^{21) 2425)}$. 著者らは本術式を31歳から73歳, 平均年齢 51.7 歳の20例に施行したが，吻合部に腫瘍の発生した 症例は経験していない. 術後早期合併症として尿管と 
$\mathrm{S}$ 状結腸（直腸）の吻合不全が 7 例（35\%）と諸家の 報告 ${ }^{26)}$ に比べ高率にみられた。これは hyperchloremic acidosis を防ぐ目的で尿管をできるかぎり肛門側に吻 合することを心掛け，20例中 8 例は尿管直腸吻合術が 行われ, 一応所期の目的は達したが尿管の過度の剝離 から栄養障害をま社き吻合不全の頻度が高くなったと 考えている27). しかし吻合部狭窄のためと思われる腎 機能低下をきたし再吻合あるいは尿管皮膚瘦造設術を 行った症例もそれぞれ 1 例あり，またその他の合併症 も他の尿管変向術を施行した群に比べ多く, 吻合方法 など手術手技に工夫，検討の必要があると考兄てい る.

尿管皮膚瘦造設術は, その手術浸襲の少いことから， 主に高齢者, 合併症のあるもの, 再手術のため膀羘摘 出術のみで長時間を要すると予想された症例などに施 行された。

尿管皮膚瘦造設術の症例では, 汪とんど全例に抗菌 剂が投与されているが，腎孟腎炎を抗こした症例は14 例 (43.8\%) と多く，カテーテル留置に併う感染が原 因と思われる腎機能障害も8例 (25\%) にみられた ${ }^{28)}$. また尿管狭窄のためカテーテルの交換ができず，尿管 皮膚瘦の再建術あるいは腎瘦造設術を行わざるを年な かった症例は 56 例中 16 例と $25 \%$ にのぼった。さらにカ テーテルの自然拔去や凝血塊などによる閉塞のため急 患として受診することもしばしばみられた。このよう なカテーテル留置に併う問題は, 患者や家族への指導 が不十分であった面もあるが，逆に注意指導が厳しす ぎてカテーテルの管理に常時気をつかっていなければ ならない精神的苦痛を訴えられることも多く，カテー テルの挿入部痛や周囲からの尿もれなどとてもカテー テルを留置しておくことの患者に与える負担は大きい といえよう。これに対し， tubeless ureterocutaneostomyは，尿管の性状により施行できないこともあり， 場合によっては尿管口形成部の狭窄などからカテーテ ルの插入やブジーを必要とすることもあるが，手術侵 襲も少く，尿路感染も汪とんどなく，前述したようう なカテーテル留置に伴う問題がないという利点があ $3^{29) 30)}$. 1983年 4 月以降, 著者らは腸管を利用しない場 合は原則として tubeless ureterocutaneostomyを試 みて括り症例数がまとまった時点で比較, 検討するつ もりである。

\section{結語}

1. 1974 年 4 月 15 日の自治医科大学附属病院の開院 より 9 年間に扣ける当教室での尿路变向術 100 例をまと
め, 特に膀胱全摘術と同時に施行された尿路変向術の 合併症について検討した。

2. 施行された尿路变向術は, 膀胱瘦造設術 8 例, 腎 瘻造設術 7 例, 尿管皮膚瘦設術 56 例, 回腸導管造設術 9 例，尿管 S 状結腸吻合術 20 例（尿管直腸吻合術 8 例 を含む)であった。

3. 原因疾患は, 膀胱腫瘍 76 例など悪性腫瘍が 92 例 で，良性疾患は 8 例であった。

4. 100 例全例の 5 年相対生存率は $51.2 \%$ で, 膀胱移 行上皮癌で膀胱全摘術を施行された 53 例の 5 年相対生 存率は $58.2 \%$ であった。

5. 膀胼全摘術とともに尿路変向術を施行された症 例の術後死亡率は4.9\%（3 例）であった。尿管 S 状結 腸（直腸）吻合術では，吻合不全をはじめとする合併 症の頻度が高く，尿管皮膚瘻造設術では，尿路感染， カテーテル留置にともなら合併症が問題であった。

本論文の要旨の一部は, 第72回日本泌尿器科学会総会で 発表した.

\section{文献}

1) U.S. Public Health Service: National Cancer Institute Monography 15. International Symposium on End Results of Cancer Therapy, Washington, 1964.

2) 栗原 登, 高野 照: 癌の治瘾率の計算方法につ いて. 癌の臨床, 11, 628-633, 1965.

3) Cox, C.E., Cass, A.S. and Boyce, W.H.: Bladder Cancer: A 26-year review. J. Urol., 101, 550-558, 1969.

4）高安久雄, 小川秋実, 北川龍一, 柿沢至忠, 岸 洋 一, 赤座英之, 石田仁男 : 膀胖腫瘍の治療成績. 日 泌尿会誌，69，669-678，1978.

5）佐川史郎, 有馬正之, 秋山隆弘, 長船匡男, 八竹 直, 高羽 津, 古武敏彦, 水谷修太郎：骨盤内悪性 腫瘍患者に対する尿路変更法. 日泌尿会誌, 66 , 785-792, 1976.

6）上門康成, 小川隆敏, 平野敦之, 船岡信彦, 澤田佳 久, 宮崎善久, 森 勝志, 戊野庄一, 新家俊明, 中 村 順, 大川順正: 膀腃癌症例飞未ける膀胱全摘 術後の治療成績. 日泌尿会誌，74，1509-1517， 1983.

7）田崎 寛：回腸導管造設術の遠隔成績。日泌尿会 誌，66，492-509， 1975.

8）神崎仁徳：回腸導管の臨床的検討.日泌尿会誌, 70, 700-708, 1979.

9) Dunn, M., Robert, J.B.M., Smith, P.J.B. and Slade, N.: The long-term results of ileal conduit urinary diversion in children. Brit. J, Urol., 51, 458-461, 1979. 
10）板谷宏楖：回腸導管における新しい antireflux ureteroileal anastomosisについて. 日泌尿会誌, 69, 844-869, 1978.

11) Richie, J.P. and Skinner, D.G: The effect of reflux on the development of pyelonephritis in urinary diversion: An experimental study. J. Surg. Research, 16, 256-261, 1974.

12) Elder, D.D., Moisy, C.U. and Ress, R.W.M. : A long-term follow up of th colonic conduit operation in children. Brit. J. Urol., 51, 462-465, 1979.

13) Harbach, L.B., Hall, R.L., Cocket, A.T.K., Kaufmann, J.J., Martin, D.C., Mimes, M.M. and Goodwin, W.E. : Ileal loop cutaneous urinary diversion: A critical review. J. Urol., 105, 511-515, 1971.

14) Schmidt, J.D., Hawtrey, C.E., Flocks, R.H. and Calp, D.A. : Complications, Results and Problems of ileal conduit diversion. J. Urol., 109, 210-216, 1973.

15）早川正道，木下英親，村井 勝，木村 哲，田崎 寛：回腸導管造設術例の術後早期扣よび晚期合併 症について。日泌尿会誌，70，1278-1286, 1979.

16) Simon, J.: Ectopia Vesicae (absence of anterior walls of bladder and pelvic abdominal parieties): Operation for directing orifices of ureters into rectum : temoprary success : Subsequent death : autopsy. Lancet, 2, 568-570, 1952.

17) Feris, D.O. and Odel, H.M.: Electrolyte pattern of the blood after bilateral ureterosigmoidostomy. J.A.M.A., 142, 634-641, 1950.

18）星野 伸, 友石純三, 国次義隆, 青木俊輔 : 尿管 S 状腸おるいは尿管直腸吻合術の臨床的検討. 日泌 尿会誌，72，1227-1237，1981.

19）高崎 登, 金田州弘, 出村 愰, 小野秀太, 沼田正 紀, 松瀬幸太郎, 岡田茂樹, 宮崎 重：尿管 S 状結 腸吻合術の臨床的検討, 泌尿紀要, 29, 1395-1399, 1983.

20) Richard, J.V., Bedard, A. and Dionne, L. : Colonic neoplasms following ureterisigmoidostomy. J. Urol., 113, 781-786, 1975.
21) Leadbetter, G.W., Zickerman, P. and Pierce,E. : Ureterosigmoidostomy carcinoma of the colon. J. Urol., 121, 732-735, 1979.

22) Urndaneta, L.F., Duffel, D., Greevy, S.D. and Aust, J.B. : Late devellpment of primary carcinoma of the colon following ureterosigmoidostomy : report of three cases and literature review. Ann. Surg., 164, 502-513, 1966.

23) Warren, R.B., Warner, T.F.C.S. and Hegez, G. R. : Late development of colonic adenocarcinoma 49 years after ureterosigmoidostomy for extrophy of the bladder. J. Urol., 124, 550-551, 1980.

24) Uehling, D.T., Starling, J.R. and Gilchrist, K. W.: Surveilance coloscopy after ureterosigmoidostomy. J. Urol., 127, 34-36, 1982.

25）高崎 登, 金田州弘, 出村 愰, 小野秀太, 沼田正 紀, 松瀬幸太郎, 匠田茂樹, 宮崎 重：尿管 S 状結 腸吻合術患者の大腸鏡による観察. 泌屢紀要, 29, 1404-1409, 1983.

26) Zinke, H. and Segura, J.W.: Ureterosigmoidostomy: Critical review of 173 cases. J. Urol., 113, 324-327, 1975.

27）徳江章彦, 松島正浩, 高田格郎, 米瀬泰行：第65回 日本泌尿器科学会総会, 口演. 日泌尿会誌, 68, 866, 1977.

28）佐々木秀平, 菅一徳, 佐々間芳文, 藤塚 勲, 瀬 尾喜久雄, 湊 修嗣, 赤坂俊幸, 久役 隆, 大堀 勉, 吉田郁彦, 小倉裕幸, 沼里 進, 半田紘一, 鈴 木信行, 大日向充, 䓪谷喜明 : 永久的尿路変向術の 腎機能の推移について. 日泌尿会誌, 74, 1394 $-1404,1983$.

29) Mahoney, F.M., Kearney, G.P. and Prather, G. C.: An improved non-intubated cutaneous uretrostomy technique for the normal and dilated ureter. J. Urol., 117, 779-782, 1977.

30) Straffon, R.A., Kyle, K. and Corvalian, J. : Techniques of cutaneous ureterostomy and results in 51 patients. J. Urol., 103, 138-146, 1970.

（1984年 5 月 1 日受付） 